1 BPA/RCP. Alcohol and the young. London: BPA/RCP, 1995.

2 Department of Health. Health survey for England. London: Department of Health, 1999

3 Williams R, Christian J, Gay M, Gilvarry E, eds. Health Advisory Service: children and young people; substance misuse services: the substance of young needs. London: HMSO, 1996.

4 World Health Organisation. Documents on nomenclature and classification. Geneva: WHO, 1981.

5 Harrison PA, Fulkerson JA, Beebe T. DSM-IV. Substance use disorder criteria for adolescents: a critical examination based on a state-wide school survey. Am f Psychiatry 1998;155:486-92.

6 American Psychiatric Association. Diagnostic and statistical manual and mental disorders (DSM-IV). Washington DC: American Psychiatric Association, 1994.

7 Harrison PA, Fulkerson JA, Beebe T. Multiple substance use amongst adolescent physical and sexual abuse victims. Child Abuse Negl 1997;21:52939.

8 Community Safety_Alcohol. Merseyside's health 2000 — the annual report of the directors of public health on Merseyside. Merseyside: Community SafetyAlcohol, 2000.

9 Goddard E. Young teenagers and alcohol in 1966. Vol 1: England. London: Office for National Statistics, 1997.

10 Miller P, Plant MA. Drinking, smoking and illicit drug use among 15 and 16 year olds in the United Kingdom. BMF 1996;313:394-7.

1 Robson WJ. Alcohol and adolescents. Fournal of Substance Misuse 1998;3:3-4. 2 Gilvarry E. Substance abuse in young people. $\mathcal{F}$ Child Psychol Psychiatry 2000;41:55-80.

13 Beattie JO, Hull D, Cockburn F. Children intoxicated by alcohol in Nottingham and Glasgow 1973-84. BMf 1986;292:519-21.
14 Community Safety-Alcohol. Merseyside's health 2000 - the annual report of the directors of public health on Merseyside. Merseyside: Community Safetythe directors of pub

15 Hughes K, MacKintosh AM, Hastings G, et al. Young people, alcohol, and designer drinks: quantitative and qualitative study. BMF 1997;314:414-18.

16 Velleman R. The development of drinking behaviours in families. Alcohol and young people: learning to cope. Conference proceedings, Addiction forum, 1992.

17 Barber JG, Gilbertson R. The drinkers children. Subst Use Misuse 1999;34: 383-402.

18 Fergusson D, Horwood J, Lynskey M. The prevalence and risk factors associated with abusive or hazardous alcohol consumption in 16 year olds. Addiction 1995;90:935-46.

19 Personal communication with children in a youth group.

20 MacCall CA. "Alcopop" use in Scottish bars: a pilot study. Fournal of Substance Misuse 1998;3:21-9.

21 Atkin CK. Effects of media alcohol messages on adolescent audiences. Adolescent Medicine State of the Art Review 1993;4:527-42.

22 Balding J. Young People in 1996. Schools Health Education Unit, University of Exeter, 1997.

23 Poskitt EM. Foetal alcohol syndrome. Alcohol Alcohol 1984;19:159-65.

24 Paton A, ed. $A B C$ of alcohol. London: BMJ Publications, 1994.

25 Shope JT, Copeland LA, Camp ME, Lang SW. Twelfth grade follow up of the effectiveness of a middle school based substance abuse prevention program. F Drug Educ 1998:28:185-97.

26 Loveland-Cherry CJ, Ross LT, Kaufman SR. Effects of a home-based family intervention on adolescent alcohol use and misuse. I Stud Alcohol Suppl 1999;13:94-102.

\title{
STAMPS IN PAEDIATRICS
}

\section{Hospitals and clinics}

The three franc Luxembourg stamp from 1957 is part of a set of three commemoratives issued to mark the "Prince Jean and Princess Josephine-Charlotte Foundation" child welfare clinic. The 1960 Bolivian stamp is from a set of eight, commemorating the founding of the Children's Hospital by the La Paz Rotary Club.
The design features a nurse and children in the foreground and the Rotary International emblem in the background. The set was split into four surface and four airmail stamps. One of the higher value airmail stamps is shown.

M K DAVIES

A J MAYNE
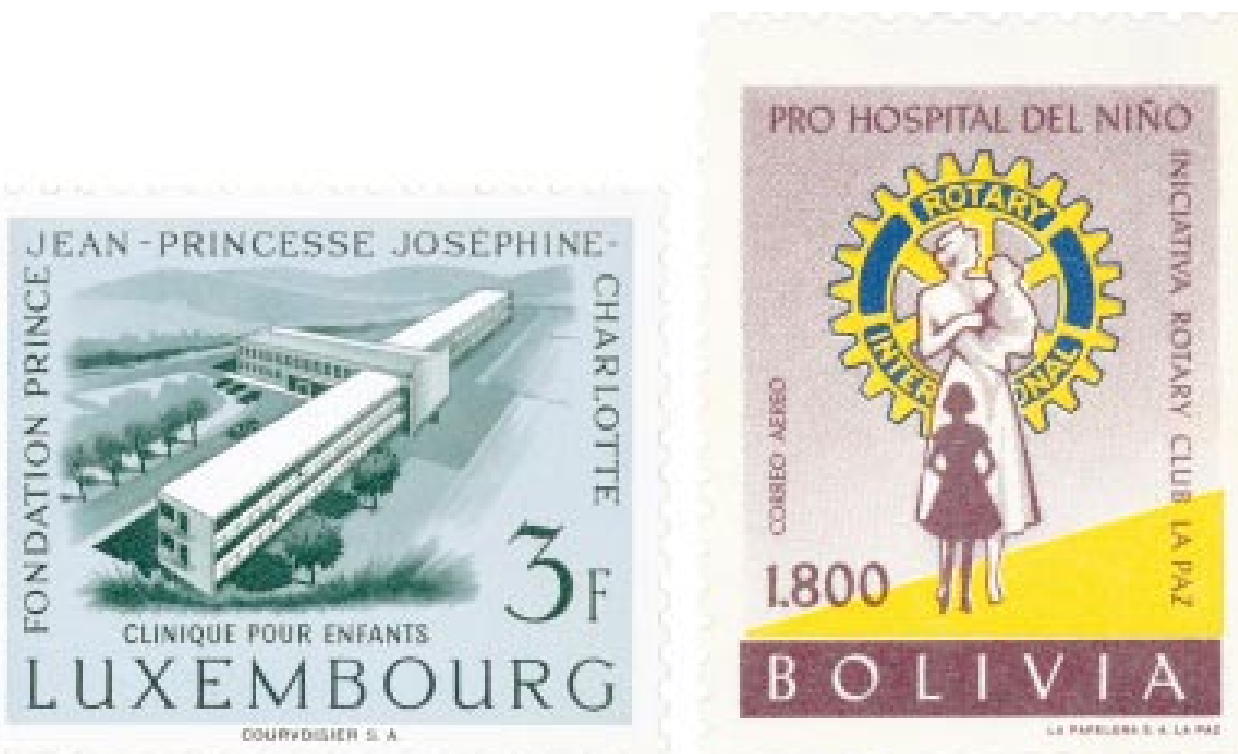